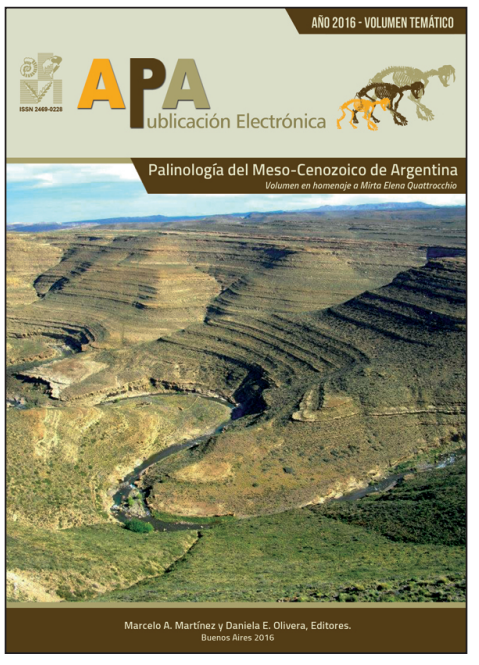

POSTGLACIAL VEGETATION AND CLIMATE CHANGES INFERRED FROM A PEAT POLLEN RECORD IN THE RÍO PIPO VALLEY, SOUTHERN TIERRA DEL FUEGO

\author{
ANA M. BORROMEI ${ }^{1}$ \\ LORENA L. MUSOTTO \\ ANDREA CORONATO ${ }^{2}$ \\ JUAN F. PONCE 2 \\ XABIER PONTEVEDRA-POMBAL ${ }^{3}$
}

\begin{abstract}
${ }^{1}$ Instituto Geológico del Sur-CONICET, Departamento de Geología, Universidad Nacional del Sur, San Juan 670, B8000ICN Bahía Blanca, Argentina. ${ }^{2}$ Centro Austral de Investigaciones Científicas-CONICET, Laboratorio de Geomorfología y Cuaternario, B. Houssay 200, 9410 Ushuaia, Argentina. ${ }^{3}$ Departamento Edafoloxía e Química Agrícola, Facultade de Bioloxía, Universidade de Santiago de Compostela, 15782 Santiago, Galicia, España.
\end{abstract}

Recibido: 27 de noviembre de 2015 - Aceptado: 24 de marzo de 2016

Para citar este artículo: Ana M. Borromei, Lorena L. Musotto, Andrea Coronato, Juan F. Ponce, and Xabier Pontevedra-Pombal (2016). Postglacial vegetation and climate changes inferred from a peat pollen record in the Río Pipo Valley, southern Tierra Del Fuego. En: M. Martínez y D. Olivera (Eds.), Palinología del Meso-Cenozoico de Argentina - Volumen en homenaje a Mirta Elena Quattrocchio. Publicación Electrónica de la Asociación Paleontológica Argentina 16 (2): 168-183.

Link a este artículo: http://dx.doi.org/10.5710/PEAPA.24.03.2016.91

DESPLAZARSE HACIA ABAJO PARA ACCEDER AL ARTÍCULO

Asociación Paleontológica Argentina Maipú $6451^{\circ}$ piso, C1006ACG, Buenos Aires República Argentina Tel/Fax (54-11) 4326-7563 Web: www.apaleontologica.org.ar

Otros artículos en Publicación Electrónica de la APA 16(2):

\section{Prieto}

ANÁLISIS E INTERPRETACIÓN DE REGISTROS PALINOLÓGICOS DE SUCESIONES ALUVIALES DE LA REGIÓN PAMPEANA: REVISIÓN E IMPLICANCIAS PARA LA RECONSTRUCCIÓN DE LA VEGETACIÓN Y EL CLIMA DURANTE EL PLEISTOCENO TARDIO-HOLOCENO

\section{Martínez \& Olivera}

JURASSIC ORGANIC-WALLED MARINE MICROPLANKTON FROM THE NEUQUÉN BASIN. DISTRIBUTION, BIOSTRATIGRAPHY AND

PALEOBIOGEOGRAPHY. A REVIEW
Borel, Guler, Navarro \& Astini

ANCIENT COASTAL ENVIRONMENTS IN A MAASTRICHTIAN - ?PALEOCENE ATLANTIC SHORELINE: A PHYTOPLANKTON APPROACH 


\title{
POSTGLACIAL VEGETATION AND CLIMATE CHANGES INFERRED FROM A PEAT POLLEN RECORD IN THE RÍO PIPO VALLEY, SOUTHERN TIERRA DEL FUEGO
}

\author{
ANA MARIA BORROMEI ${ }^{1}$, LORENA LAURA MUSOTTO ${ }^{1}$, ANDREA CORONATO², JUAN FEDERICO PONCE², AND XABIER PONTEVEDRA- \\ POMBAL ${ }^{3}$
}

${ }^{1}$ Instituto Geológico del Sur-CONICET, Departamento de Geología, Universidad Nacional del Sur, San Juan 670, B8000ICN Bahía Blanca, Argentina. borromei@criba.edu.ar; loremusotto@criba.edu.ar

${ }^{2}$ Centro Austral de Investigaciones Científicas-CONICET, Laboratorio de Geomorfología y Cuaternario, B. Houssay 200,9410 Ushuaia, Argentina. acoronato@cadic-conicet.gob.ar; jfponce@gmail.com

${ }^{3}$ Departamento Edafoloxía e Química Agrícola, Facultade de Bioloxía, Universidade de Santiago de Compostela, 15782 Santiago, Galicia, España. xabier.pombal@usc.es

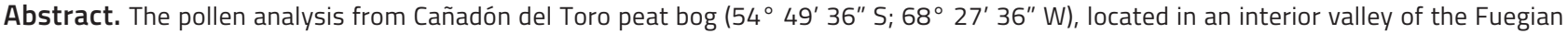
Andes, provides information about vegetation and climate changes during the last 13,500 years. The results indicate the postglacial development of steppe-like vegetation under drier and colder conditions than today, followed by the expansion of Nothofagus into the valley after 10,350 cal. yr BP. At this time, the predominance of a forest-steppe ecotone suggests warm conditions and an increase in moisture availability. By about 6,700 cal. yr BP, the closed-canopy Nothofagus forest spread under cold and wet conditions. The mire environment also reflects the increasing trend of effective moisture changing from an initial minerotrophic Cyperaceae fen to an ombrotrophic Sphagnum bog development.
\end{abstract}

Key words. Vegetation and climate history. Lateglacial-Holocene. Interior valleys. Tierra del Fuego.

Resumen. CAMBIOS DE LA VEGETACIÓN Y CLIMA POSTGLACIAL INFERIDOS A PARTIR DE UN REGISTRO POLÍNICO DE UNA TURBERA EN EL

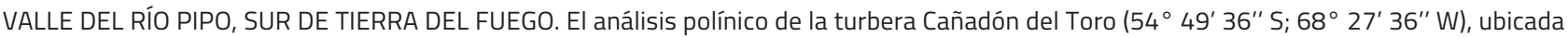
en un valle interior de los Andes Fueguinos, brindó información sobre los cambios de la vegetación y del clima durante los últimos 13.500 años. Los resultados indicaron el desarrollo postglacial de una vegetación de estepa bajo condiciones más secas y frías que las actuales, seguidas por la expansión de Nothofagus en el valle con posterioridad a los 10.350 años cal. AP. Durante este período, la predominancia del ecotono bosque-estepa sugiere condiciones más cálidas y un incremento en la disponibilidad de humedad. Alrededor de los 6.700 años cal. AP, el bosque cerrado de Nothofagus se expande bajo condiciones frías y húmedas. El ambiente de la turbera también refleja el paulatino incremento de humedad efectiva cambiando desde una turbera minerotrófica de Cyperaceae a una ombrotrófica de Sphagnum.

Palabras clave. Historia de la vegetación y el clima. Tardiglacial-Holoceno. Valles interiores. Tierra del Fuego.

THE VEGETATION and climate reconstructions after deglaciation from Isla Grande de Tierra del Fuego have been carried out from several pollen records mainly located at low-elevation sites along the Canal Beagle, southernmost part of the island (Markgraf, 1983, 1991, 1993; Heusser, 1989a,b, 1990, 1995, 1998, 2003; Borromei and Quattrocchio, 2001, 2007; Pendall et al., 2001; Grill et al., 2002; Markgraf and Huber, 2010; Borromei et al., 2014). In contrast, few palynological studies consider the inner valleys of the Fuegian Andes (Borromei, 1995; Mauquoy et al., 2004; Borromei et al., 2007; Borromei and Quattrocchio, 2008), or at high-elevation sites (Markgraf, 1993; Borromei et al., 2010; Markgraf and Huber, 2010). Taken together, the pollen data show a deglacial open ground vegetation dominated by grasses, dwarf shrub heaths and scrubs, with scattered Nothofagus Blume 1850 trees. After 11,500 cal. yr BP, the Nothofagus woodland containing grasses, composites, and ferns dominated the landscape under warmer and drier climatic conditions than today, and high fire activity. The closed-canopy forest developed after ca. 7000 cal. yr BP, under colder and 
wetter climate conditions. These changes in vegetal paleocommunities have been interpreted in terms of variations in the amount of precipitation of westerly origin related to shifts in the latitudinal location and/or strength of the Southern Westerly Winds (SWW), Antarctic sea-ice extent, and position of the Antarctic Polar Front (Markgraf and Huber, 2010; Kilian and Lamy, 2012).

The mountain valleys of the Fuegian Andes, tributaries to the Canal Beagle valley, show the effect of extensive Pleistocene glacier erosion (Coronato, 1995; Rabassa et al., 2000). These valleys were occupied by multiple alpine-type glaciers, ranging from 20 to $30 \mathrm{~km}$ in length, though smaller, single-valley glaciers were also present (Rabassa, 2008). They were fed by local cirques, independent of the Cordillera Darwin mountain ice sheet, from where the main glacier (the Beagle Glacier) was nourished. As in all interdependent ice system, the glacial activity in these tributary valleys was controlled by the glaciological behavior of the main ice stream and regional climatic variations. Most likely, these local glaciers were more severely affected by the abrupt climate change, and thus receded fast (Coronato, 1990; Rabassa, 2008).

The present contribution gives insight into the regional and local vegetation dynamics for the interior Andean valleys on the Andean Pacific slope during the last 13,500 yr. The studied peat core was collected from a peat bog (Cañadón del Toro, Fig. 1.1-2) located into the Río Pipo valley, which constitutes the oldest pollen record from low interior valleys. The pollen/spores analysis provides valuable information about the development of plant communities and environmental changes since deglaciation. The results are compared with other pollen records retrieved from sites located at different altitudes in the southernmost part of Tierra del Fuego (Tab. 1) to obtain a better understanding of the regional vegetation and climate patterns during the Lateglacial and Holocene times.

\section{ENVIRONMENTAL SETTING}

The studied site, herein named as Cañadón del Toro (TCT), is a raised bog $\left(54^{\circ} 49^{\prime} 36^{\prime \prime} \mathrm{S} ; 68^{\circ} 27^{\prime} 36^{\prime \prime} \mathrm{W}\right.$; $90 \mathrm{~m}$ a.s.l., Fig. 1.3-4) located in the Río Pipo valley, Tierra del Fuego National Park, 3 km north of Canal Beagle coast, in the southern part of Isla Grande de Tierra del Fuego. Canal Beagle is a marine channel $200 \mathrm{~km}$ long on a W-E trend and constitutes a connection between the Atlantic and Pacific oceans. It is a former tectonic valley that was completely covered by ice during the Last Glacial Maximum (LGM) (Rabassa et al., 2000), with ice limits reaching a maximum extent by ca. 25,000 cal. yr BP (Rabassa, 2008).

The peat bog reported in this study is 70 ha in extent. It was developed in a glacial basin, and then transformed into a lake, located between the Cañadón del Toro terminal moraines and the sub-glacially eroded rocky hills which enclose part of the valley $2 \mathrm{~km}$ to the east. The sides of the lake received colluvium deposits from the valley (Coronato, 1993). The peat bog forms an ombrotrophic type with hummocky surface formed mainly by Sphagnum magellanicum Brid. 1798 and S. fimbriatum Wilson in J. D. Hooker 1847 and covered by Empetrum rubrum Vahl ex Willd. 1806 with minor amounts of Cyperaceae, Juncaginaceae and Juncaceae, and scattered low shrubby Nothofagus antarctica (Forster f.) Oersted 1871. It is surrounded by forest communities of $N$. pumilio (Poeppig and Endl.) Krasser 1896.

\section{MODERN CLIMATE AND VEGETATION}

The climate of Isla Grande de Tierra del Fuego is determined by its upper middle-latitude location in the belt of prevailing SWW, in the path of eastward moving cyclones, not far from the Antarctic ice. The latitudinal position and strength of the SWW are controlled by the intensity and latitudinal location of the subtropical high-pressure cells in the Pacific and the circum-Antarctic low-pressure trough (Tuhkanen, 1992). Regional climate is highly oceanic in the

Figure 1. 1, Modern-day vegetation map of the Isla Grande de Tierra del Fuego with the mean annual precipitation (mm) isohyets and the peat core location (pink star). The highlighted area in the rectangle is shown enlarged in b (modified from Tuhkanen, 1992). 2, Location of the study sites as well as of the other sites referred to in the text. 3, Overall view of Cañadón del Toro peat bog to the northwest; low hills covered by forest are the terminal moraines of the Cañadón del Toro valley. 4, Detail photograph of the coring site; at the back La Portada rocky-hill which limits the valley to the south. 


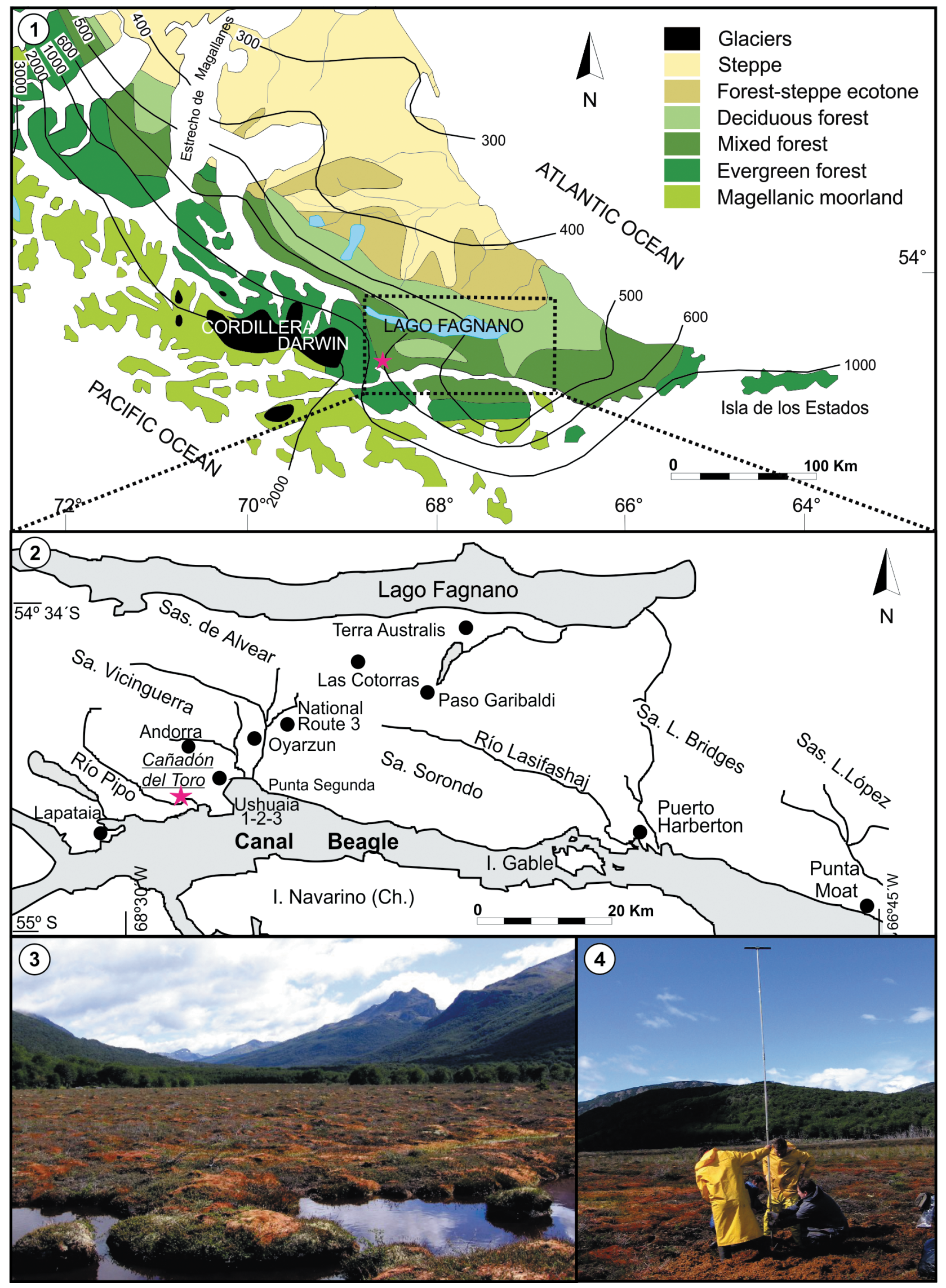


TABLE 1 - Late Quaternary pollen records from different peat bogs and exposures of Isla Grande de Tierra del Fuego discussed in this study. The sites are listed according to their altitude above sea level ( $m$ a.s. I).

\begin{tabular}{|c|c|c|c|c|c|c|c|}
\hline Pacific Andean slope & Sites & $\begin{array}{l}\text { Altitude } \\
\text { (m.a.s.l.) }\end{array}$ & $\begin{array}{l}\text { Lat. } \\
\text { South }\end{array}$ & $\begin{array}{l}\text { Long. } \\
\text { West }\end{array}$ & $\begin{array}{l}\text { Core depth } \\
\quad(\mathrm{cm})\end{array}$ & $\begin{array}{l}\text { Age range } \\
\text { (ka cal BP) }\end{array}$ & References \\
\hline \multirow{4}{*}{$\begin{array}{l}\text { Low Andean } \\
\text { valleys }\end{array}$} & Cañadón del Toro & 90 & $54^{\circ} 49^{\prime}$ & $68^{\circ} 27^{\prime}$ & 678 & $0-13.5$ & This paper \\
\hline & Valle de Carbajal & 140 & $54^{\circ} 44^{\prime}$ & $68^{\circ} 12^{\prime}$ & 580 & $\begin{array}{c}0-? \\
\text { Late Glacial }\end{array}$ & Borromei et al. (2007) \\
\hline & Valle de Andorra & 180 & $54^{\circ} 45^{\prime}$ & $68^{\circ} 18^{\prime}$ & 690 & $0-10.5$ & Borromei (1995) \\
\hline & National Route 3 & 270 & $54^{\circ} 43^{\prime}$ & $68^{\circ} 90^{\prime}$ & exposure & 12.0 & Borromei et al. (2007) \\
\hline \multirow{2}{*}{$\begin{array}{c}\text { High Andean } \\
\text { valleys }\end{array}$} & Las Cotorras & 420 & $54^{\circ} 41^{\prime}$ & $68^{\circ} 02^{\prime}$ & 480 & $0-8.0$ & Borromei et al. (2010) \\
\hline & Paso Garibaldi & 420 & $54^{\circ} 43^{\prime}$ & $67^{\circ} 50^{\prime}$ & 306 & $0-14.0$ & Markgraf and Huber (2010) \\
\hline \multirow{6}{*}{$\begin{array}{c}\text { Lowlands } \\
\text { (Canal Beagle coast) }\end{array}$} & Ushuaia 3 & 7 & $54^{\circ} 48^{\prime}$ & $68^{\circ} 23^{\prime}$ & 550 & $0-13.9$ & Heusser (1998) \\
\hline & Puerto Harberton & 10 & $54^{\circ} 52^{\prime}$ & $67^{\circ} 53^{\prime}$ & 104 & $0-17.7$ & $\begin{array}{l}\text { Heusser (1990); Markgraf } \\
\text { and Huber (2010) }\end{array}$ \\
\hline & Lapataia & 18 & $54^{\circ} 51^{\prime}$ & $68^{\circ} 32^{\prime}$ & 510 & $0-11.6$ & Heusser (1998) \\
\hline & Punta Moat & 40 & $54^{\circ} 58^{\prime}$ & $66^{\circ} 44^{\prime}$ & $450-100$ & $5.0-11.2$ & Borromei et al. (2014) \\
\hline & Ushuaia 2 & 80 & $54^{\circ} 47^{\prime}$ & $68^{\circ} 18^{\prime}$ & 820 & $0-14.4$ & Heusser (1998) \\
\hline & Ushuaia 1 & 280 & $54^{\circ} 47^{\prime}$ & $68^{\circ} 23^{\prime}$ & 700 & $0-13.8$ & Heusser (1998) \\
\hline
\end{tabular}

west and south parts of the archipelago and increasing continental towards the east and north. The daily temperature in summer (January) at Ushuaia averages $9.2^{\circ} \mathrm{C}$ and in winter (July) $1.6^{\circ} \mathrm{C}$; the mean annual precipitation is $574 \mathrm{~mm}$ (Prohaska, 1976).

Vegetation composition follows the climatic and topographic gradients across Tierra del Fuego (Moore, 1983; Tuhkanen, 1992) (Fig. 1.1). The modern vegetation in the north corresponds to the Fuego-Patagonian Steppe with a mean annual precipitation less than $400 \mathrm{~mm}$. The tussock grassland of Festuca gracillima Hooker f. 1847 covers the area, grading into scrub of shrubby composites or into dwarf shrub heaths of Empetrum rubrum (Moore, 1983; Collantes et al., 1989). Contact of steppe with deciduous forest occurs through an ecotone under precipitation of 350 to $500 \mathrm{~mm}$ annually (Tuhkanen, 1992). Subantarctic Deciduous Forest is represented by two species of southern beech, Nothofagus pumilio (lenga) and $N$. antarctica (ñire), which grow to an average altitudinal limit of 550-600 m a.s.l. and become dominant where precipitation exceeds $450 \mathrm{~mm} \mathrm{yr}^{-1}$. Towards the south and west of Tierra del Fuego, the annual precipitation rises to over $700 \mathrm{~mm}$ and the Subantarctic Evergreen Forest develops, which is dominated by N. betuloides (Mirbel) Oersted 1871 (guindo), accompanied by Drimys winteri Forster and Forster f. 1775 (canelo), Maytenus magellanica (Lam.) Hooker f. 1847 (maitén) and abundant ferns and mosses. Initially, N. betuloides is intermingled with $N$. pumilio in an association distinguished as Mixed Evergreen-Deciduous Forest which can be better considered as ecotonal between the two communities (Moore, 1983). 
Magellanic moorland occurs beyond the forest along the exposed outermost coast under conditions of increased precipitation (>1500 $\mathrm{mm} \mathrm{yr}^{-1}$ ), high winds and poor drainage. It consists of a mosaic of barren rock, marginal grassland, cushion bogs, scrub, and fragments of evergreen forest (Moore, 1983). Above treeline in the Fuegian cordillera, Andean tundra is comprised of cushion plants, dwarf shrub heaths, and meadow communities (Pisano, 1977; Heusser, 2003).

\section{MATERIAL AND METHODS}

\section{Stratigraphy and chronology, age-depth model}

A $678 \mathrm{~cm}$ sediment-peat core (221 samples) from the mire was obtained using a Russian-type peat corer (chamber length $0.5 \mathrm{~m}$ and $5 \mathrm{~cm}$ diameter) (Fig. 1.4). During sectioning of the samples, the morpho-stratigraphic consistency was preserved. Thus, the first $50 \mathrm{~cm}$ were taken in varying thicknesses by high morphological variability of peat. The remainder of the core was taken every 2 or $3 \mathrm{~cm}$ thick. The volcanic ash layer was also individualized. Eleven AMS radiocarbon age determinations established the chronology for the section (Tab. 2). They were obtained at Ångström Laboratory-Tandem Laboratory, Uppsala Univer-

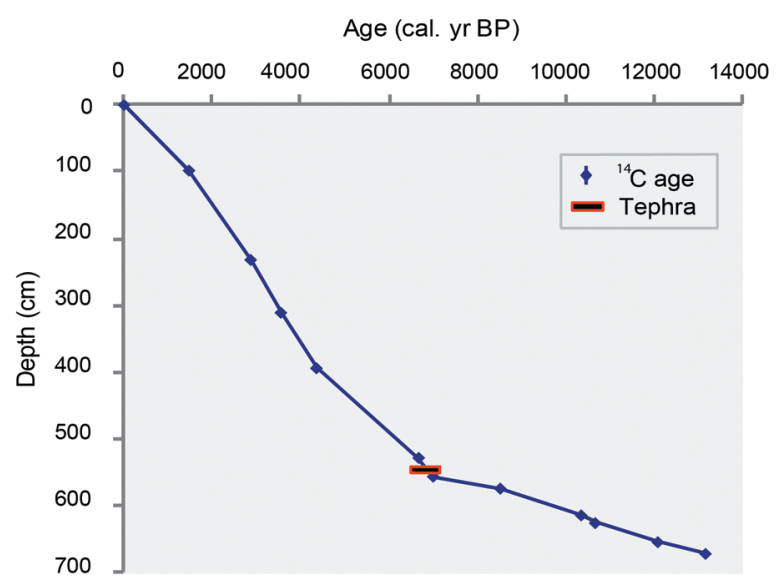

Figure 2. Age-depth model for the Cañadón del Toro peat core.

sity (Sweden), and at National Accelerator Centre (CNA, CSIC, Sevilla, Spain). Calibrated dates were calculated using the program CALIB 7.1 software (Stuiver et al., 2015) and the Southern Hemisphere curve SHCal13 (Hogg et al., 2013). The average dates, taking into account the maximum probability interval at 2 sigma ranges, which is considered a robust statistical value (Telford et al., 2004), were used to build an age-depth model by linear interpolation (Fig. 2).

TABLE 2 - Radiocarbon and calibrated ages from Cañadón del Toro peat core.

\begin{tabular}{|c|c|c|c|c|c|c|c|c|}
\hline Samples & $\begin{array}{l}\text { Depth } \\
\text { (cm) }\end{array}$ & $\begin{array}{c}{ }^{14} \text { C age } \\
(B P)\end{array}$ & $\begin{array}{c}\text { Cal age } \\
(B P)\end{array}$ & $\begin{array}{c}\text { Maximum } \\
2 \sigma B P\end{array}$ & $\begin{array}{l}\text { Minimum } \\
2 \sigma B P\end{array}$ & $\delta^{13} C \%$ & $\begin{array}{l}\text { Sample } \\
\text { material }\end{array}$ & $\begin{array}{c}\text { Analysis } \\
\text { No. }\end{array}$ \\
\hline TCT-26 & 100 & $1655 \pm 25$ & 1504 & 1564 & 1425 & -27.1 & peat & Ua-35766 \\
\hline TCT-69 & 233 & $2830 \pm 30$ & 2887 & 2968 & 2784 & -26.6 & peat & Ua-35767 \\
\hline TCT-94 & 312 & $3380 \pm 35$ & 3573 & 3644 & 3464 & -27.0 & peat & Ua-35768 \\
\hline$T C T-121$ & 395 & $3980 \pm 35$ & 4376 & 4516 & 4470 & -27.2 & peat & Ua-35769 \\
\hline$T C T-164$ & 529 & $5910 \pm 40$ & 6689 & 6790 & 6558 & -27.3 & peat & Ua-35771 \\
\hline$T C T-173$ & 556 & $6170 \pm 70$ & 7019 & 7178 & 6796 & -28.66 & tephra & CNA442 \\
\hline$T C T-179$ & 575 & $7800 \pm 50$ & 8531 & 8627 & 8422 & -27.6 & peat & Ua-35773 \\
\hline TCT-192 & 615 & $9235 \pm 55$ & 10,359 & 10,507 & 10,237 & -27.4 & peat & Ua-35774 \\
\hline TCT-196 & 626 & $9490 \pm 55$ & 10,689 & 10,516 & 10,811 & -27.4 & peat & Ua-35775 \\
\hline$T C T-210$ & 654.5 & $10,290 \pm 65$ & 11,959 & 12,175 & 11,705 & -27.6 & peat & Ua-35776 \\
\hline TCT-218 & 671.5 & $11,280 \pm 120$ & 13,098 & 13,320 & 12,800 & -32.79 & organic matter & CNA443 \\
\hline
\end{tabular}


All dates mentioned in this paper are given as calibrated years (BP).

\section{Geochemical analysis}

Inorganic ash content was obtained by dry ashing at $600{ }^{\circ} \mathrm{C}$ for 12 hours (Pontevedra-Pombal et al., 2013), expressing the results as the percentage of dry peat mass $\left(105^{\circ} \mathrm{C}\right)$ according to the equation:

Ash $(\%)=(a / b) \times 100$

where $\mathrm{a}$ is the weight of the burned sample, and $\mathrm{b}$ is the weight of the dried sample at $105^{\circ} \mathrm{C}$.

The content of aluminum extractable with pyrophosphate (Alp) was determined from an extraction with $0.1 \mathrm{M}$ Na-pyrophosphate (pH 10) in a sample/solution ratio of 1:100, which was stirred for 16 hs. The obtained suspension was centrifuged (15 min at 2500 rpm, with three drops of 'superfloc') (Buurman et al., 1996) and the supernatant filtered. Aluminium in the extracts was measured using flame atomic absorption spectrometry. The results, which are the mean of duplicate analysis that are less than $10 \%$ apart, are expressed to oven dry weight $\left(105^{\circ} \mathrm{C}\right)$.

The X-ray diffraction (XRD) allows identifying the mineral components and the crystalline state of a sample. The amorphous phases generate a broad diffuse pattern, which helps increase the background noise in the form of broad bands. For analysis of the mineral composition of the tephra, $0.05 \mathrm{~g}$ of finely ground and homogenized sample was used. The equipment used was a PW1710 Philips Diffractometer with a PW1820/00 vertical goniometer and Bragg-Brentano $\theta / 2 \theta$ geometry, generator with glass tube of $2.2 \mathrm{~kW}$, PW 2773/00 Cu anode, PW1711/10 proportional detector, and PW1752/00 graphite monochromator. The measurement time was 1 second per step (step: $0.02^{\circ}, 2-65^{\circ}$ 2Theta). EVA DIFFRAC plus software (Bruker AXS 2001) was used for semi-quantification.

\section{Pollen/spores analysis}

The samples were prepared in the Laboratorio de Palinología (INGEOSUR-CONICET, Universidad Nacional del Sur, Argentina) according to standard techniques (Faegri and Iversen, 1989). Prior to treatment, Lycopodium clavatum spore tablets (Stockmarr, 1971) were added to each sample in order to calculate pollen concentration per gram of sediment (grains gr $^{-1}$ ). Frequencies (\%) of tree, shrub and herb pollen were calculated from sums mostly of $\geq 300$ grains. Frequencies (\%) of pollen of aquatic plants and spores of cryptogams were calculated separately and related to the sum of the total land pollen (TLP). "Other shrubs and herbs" include taxa with low frequency values, such as Berberis L. 1753, Brassicaceae, Chenopodiaceae, Asteraceae subf. Cichorioideae, Astelia pumila (Forster f.) Gaudich. 1825, Latua Phil. 1858, Labiateae, Plumbaginaceae, and Plantago L. 1753 We combined pollen from the evergreen species $N$. betuloides and the deciduous $N$. pumilio and $N$. antarctica, given the difficulty in species separation and report these as "Nothofagus dombeyi-type".

Plotting of palynological diagrams and statistical analysis were carried out using Tilia 2.0.1 program (Grimm, 2004). The pollen/spores spectrum was subdivided into zones based on visual inspection of the pollen record and a stratigraphically constrained cluster analysis using Edwards and Cavalli-Sforza's chord distance (TGView 2.0.2, Grimm, 2004). For the analysis, all taxa with percentages of $\geq 1 \%$ of the sum of terrestrial pollen were included. The fossil pollen spectra were compared with modern pollen datasets from surface soil samples (Heusser, 1989a; Trivi de Mandri et al., 2006; Musotto et al., 2012) and with present-day plant formations from Tierra del Fuego (Pisano, 1977; Heusser, 2003).

\section{RESULTS}

\section{Stratigraphy and chronology}

The studied core consisted of organic rich layers interspersed with bluish gray clays [678-624 cm]. The overlying sediments consisted of strongly decomposed black peat [624-584 cm], changing into moderately decomposed dark brown peat [584-557 cm]. A 13-cm-thick tephra layer [557-544cm] was recognized. From 544 to $520 \mathrm{~cm}$ the core consisted of highly humified brownish black peat, which was overlain by dark brown peat between 520 and $403 \mathrm{~cm}$. From 403 to $74 \mathrm{~cm}$ the core consisted of dark brown Sphagnum peat interspersed with reddish Sphagnum peat containing woody detritus. The upper $74 \mathrm{~cm}$ of the core were composed by reddish unhumified Sphagnum peat.

In the range of ca.570-534 cm a turnaround in the in- 
organic material concentration (ash) is detected. At an average depth of $550 \mathrm{~cm}$, this drastic increase represents a rise of almost 6 and 12 times the ash content detected in the first (from ca. 10,100 to 8500 cal. yr BP; average: 7.02\%) and second (last 6800 cal. yr BP; average: 2.55\%) ombrotrophization cycles, respectively (Fig. 3). This inorganic material has a high content of Alp indicating their high reactivity, characteristic of amorphous organomineral complex (Garcia-Rodeja et al., 2004). In correlation with this chemical feature, the $\mathrm{X}$-ray diagram is clearly dominated by a large amorphous band (noise) where amorphous quartz and albite are detected, typical of an andesitic volcanic ash (Fig. 4).

The tephra layer was dated at $6170+/-70{ }^{14} \mathrm{C}$ yr BP (556-553 cm; 7178-6796 cal. yr BP). The source of this tephra is unknown, but its age is similar within statistics to the age of the greenish andesitic tephra derived from a large explosive eruption $\left(\mathrm{H}_{1}\right)$ of the Volcán Hudson $\left(45^{\circ} 54^{\prime}\right.$ S; 72 58' W, $1905 \mathrm{~m}$ a.s.l.), regionally dated 7960-7423 cal. yr BP (Stern, 2008), and widely distributed in Tierra del Fuego. This volcano is located in the southern portion of the Zona Volcánica Sur (ZVS, 33-46 S), more than $900 \mathrm{~km}$ farther northwest. $\mathrm{H}_{1}$ has also been identified in the Harberton raised bog (Kilian et al., 2003), $75 \mathrm{~km}$ east of TCT. Xray spectra obtained for the tephra located in TCT and Harberton raised bog show a close resemblance (Fig. 4).

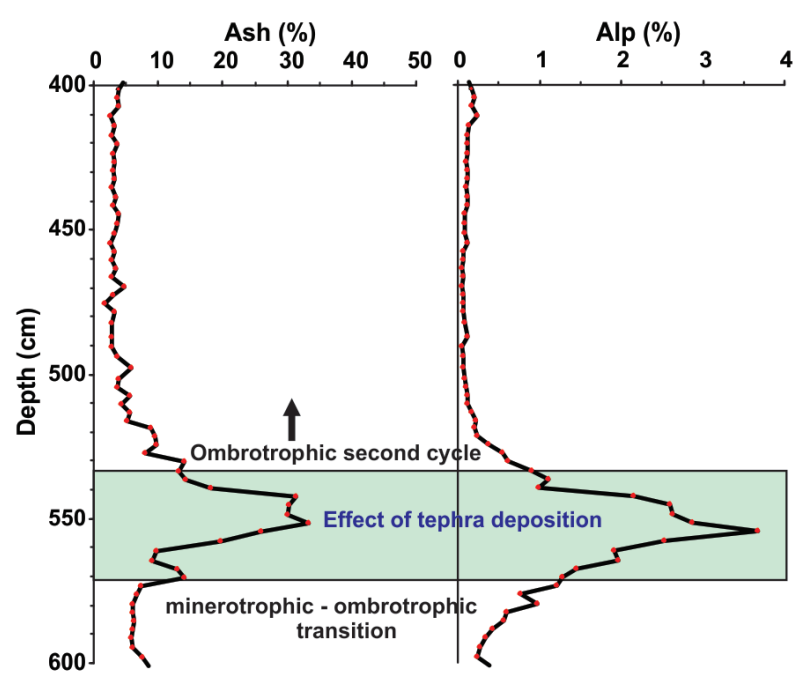

Figure 3. Effect of deposition of tephra on the inorganic ash and sodium pyrophosphate extractable Al content in Cañadón del Toro peat bog.

\section{Pollen/spores analysis}

The pollen record from Cañadón del Toro has been divided into three local pollen assemblage zones, CDT-1 to CDT-3 (Fig. 5). Zone CDT-3 was divided into three subzones. The main pollen concentration values (Fig. 6) were calculated in order to assess the independent behavior of pollen types and to add a new dimension to the study of vegetation history. From the lower to the upper part of the section, they are:

Zone CDT-1 (678-613.5 cm; 13,500-10,350 cal. yr BP). This zone is characterized by the dominance of Poaceae (28-77\%), accompanied by Asteraceae subf. Asteroideae (48\%), Acaena Mutis ex L. 1771 (32\%), Empetrum rubrum (28\%), Gunnera L. 1767 (12\%), and Caltha L. 1753 (<10\%). Other herbaceous taxa such as Rubiaceae, Apiaceae, Gentiana L. 1753, Caryophyllaceae and Azorella Lam. 1783 are present with low frequencies $(<5 \%)$. Nothofagus dombeyitype records low values $(0.3-13 \%)$ increasing towards the end of the zone $(23 \%)$. Cyperaceae shows percentages of $43 \%$ at the base and increases rapidly to reach its maximum abundance (68\%) followed by an abrupt decline toward the end of the zone (3\%). Total pollen concentration is low (3000 grains $\mathrm{gr}^{-1}$ ) at the onset of the sequence increasing up to 191000 grains gr $^{-1}$ towards the end of the zone. It is contributed mainly by Poaceae (1300-105200 grains gr ${ }^{-1}$ ), Asteraceae subf. Asteroideae (165-62500 grains gr-1), and E. rubrum (335-4500 grains gr $^{-1}$ ). Among the aquatic taxa, Cyperaceae records its highest values up to 171200

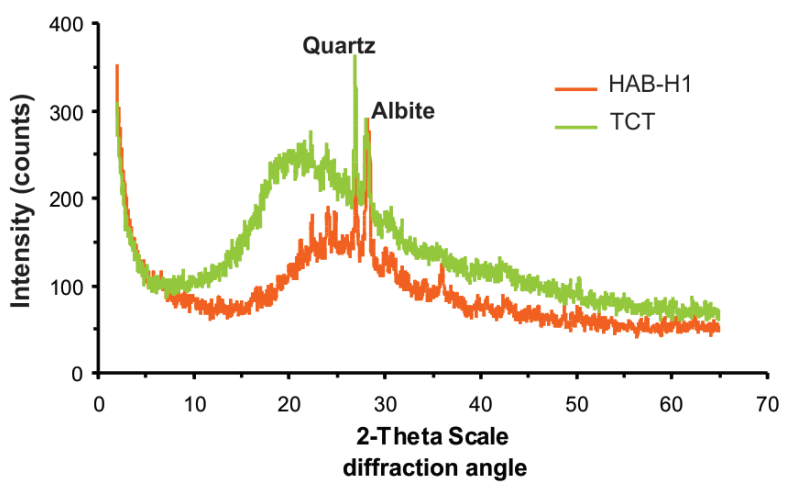

Figure 4. X-ray spectra of Haberton $\left(\mathrm{HAB}-\mathrm{H}_{1}\right)$ and Cañadón del Toro (TCT) peat bogs. 

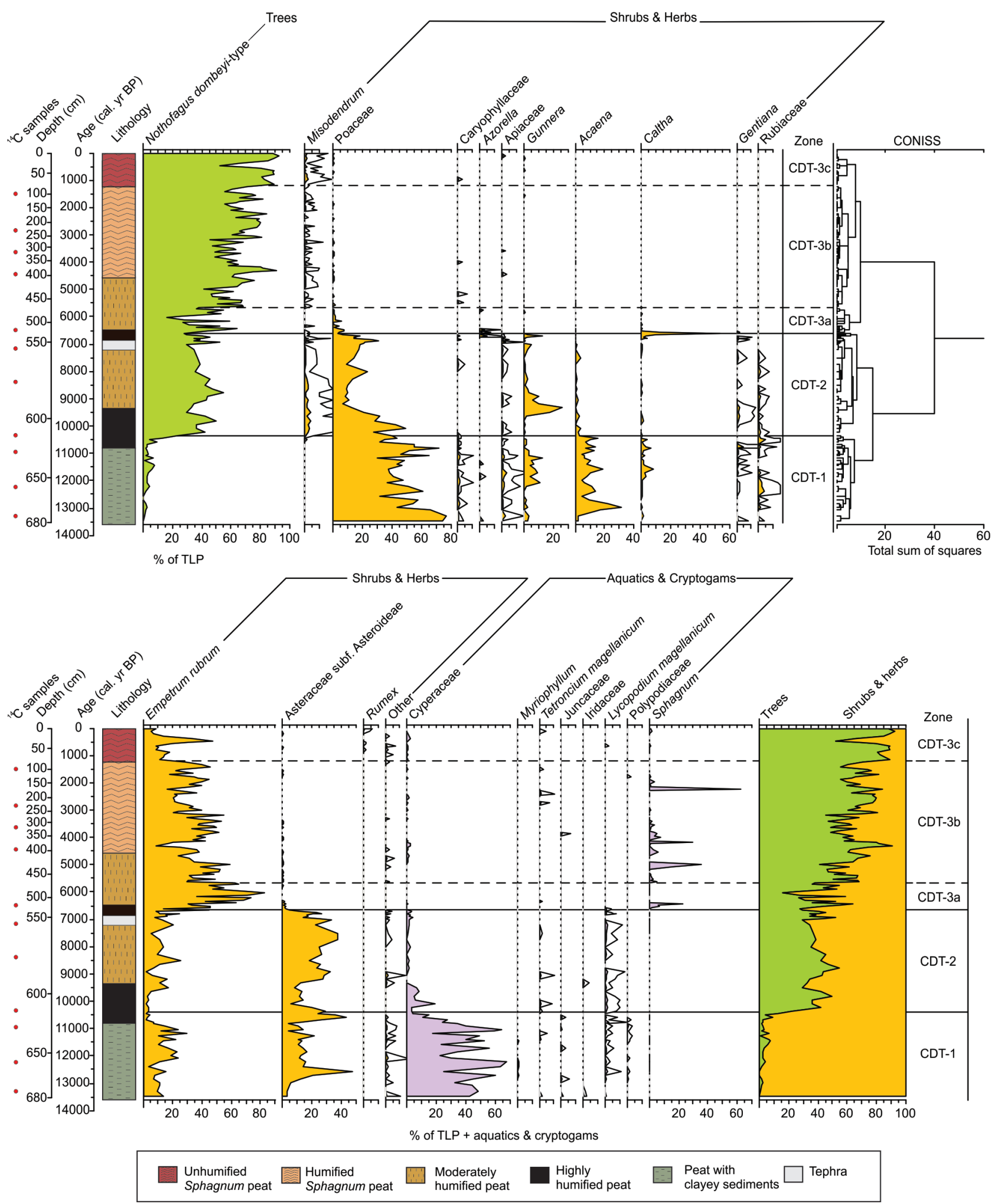

Figure 5. Fossil pollen/spore frequency (\%) diagram and lithology at Cañadón del Toro mire. Outline curve represents an exaggeration percentage curve (10x) for minor taxa. 


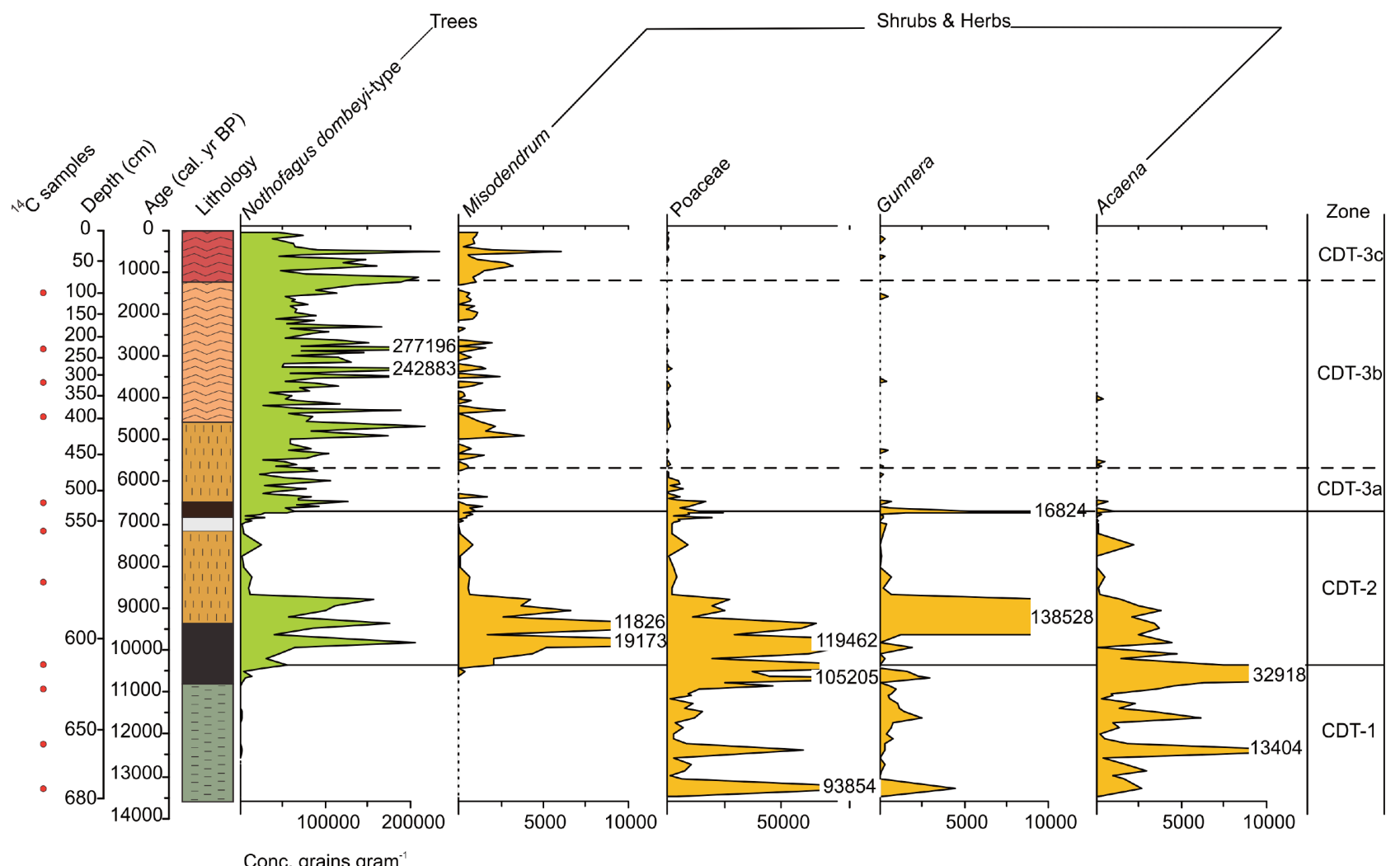
Conc. grains gram

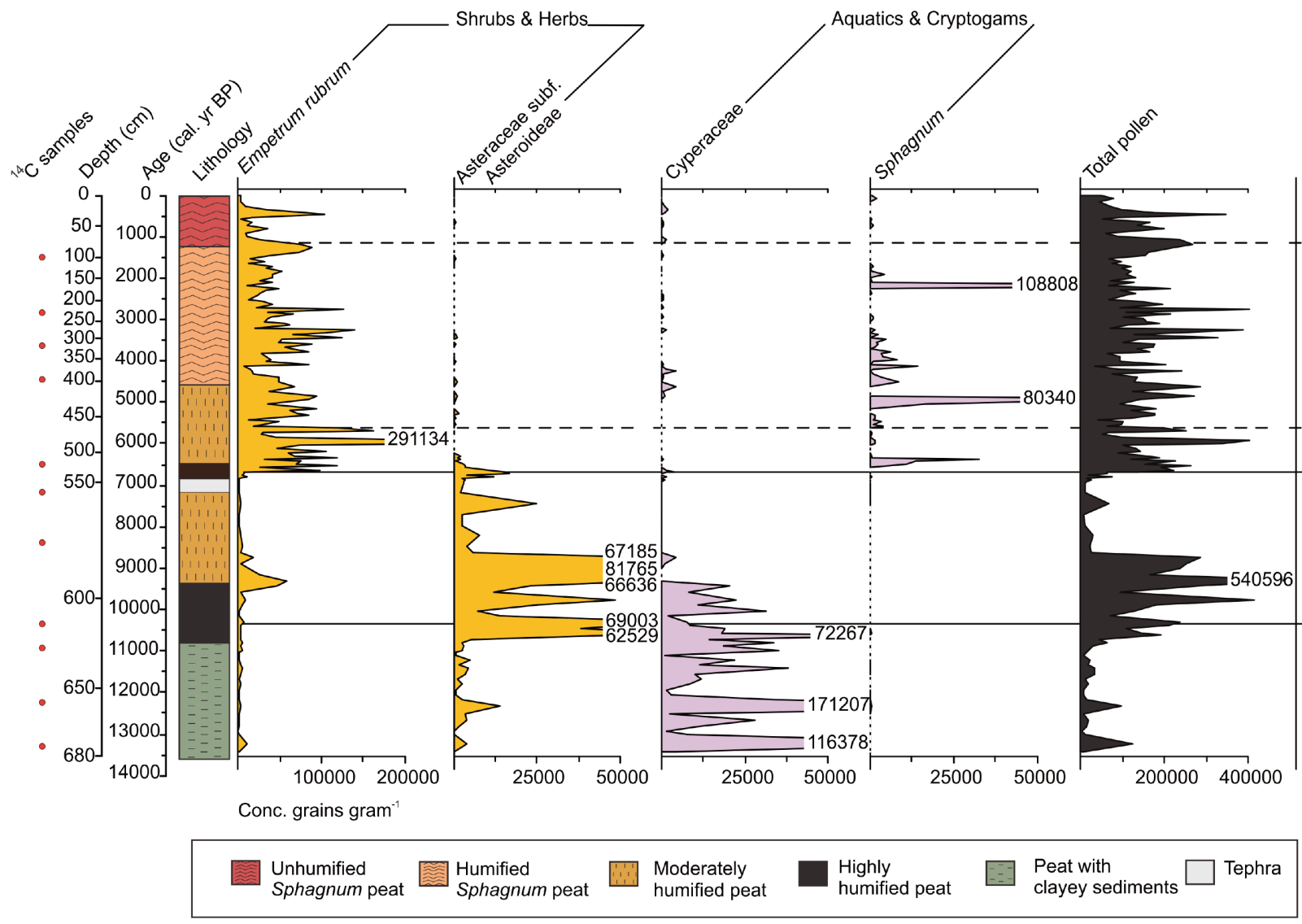

Figure 6. Fossil pollen concentration diagram (grains gram-1) and lithology at Cañadón del Toro peat bog. 
grains $\mathrm{gr}^{-1}$. N. dombeyi-type concentration is less than 5500 grains $\mathrm{gr}^{-1}$ throughout the zone.

Zone CDT-2 (613.5-530.5 cm; 10,350-6700 cal. yr BP). In this zone Nothofagus dombeyi-type (29-55\%) expands abruptly along with decreases in Poaceae (8-49\%), Acaena $(<4 \%)$ and Caltha $(<4 \%)$. Asteraceae subf. Asteroideae (38\%) and Empetrum rubrum (25\%) maintain similar percentages compared with those of the previous zone CDT-1. Misodendrum Banks ex DC. 1830, a hemiparasite on Nothofagus species, appears in low values $(5 \%)$. Gunnera $(26 \%)$ reaches its highest abundance in the record followed by its decline toward the end of the zone. Among the aquatic taxa, Cyperaceae decreases to $<19 \%$. Total pollen concentration exhibits an increasing trend (up to 540-600 grains gr-1) in the lowermost part of the zone. N. dombeyi-type (206500 grains gr ${ }^{-1}$ ), Poaceae (119500 grains gr-1), Asteraceae subf. Asteroideae (81800 grains gr $^{-1}$ ) and E. rubrum (57500 grains $\mathrm{gr}^{-1}$ ) show high values, while Cyperaceae declines (22000 grains gr $^{-1}$ ). Total pollen concentration values record an abrupt decline (<66500 grains $\mathrm{gr}^{-1}$ ) between 8800 and 7000 cal. yr BP, increasing toward the end of the zone up to 73400 grains gr $^{-1}$.

Zone CDT-3 (530.5-0 cm; 6700-0 cal. yr BP). Three subzones can be differentiated on the basis of proportional changes between Nothofagus dombeyi-type and Empetrum rubrum.

Subzone CDT-3a (530.5-469.5 cm; 6700-5650 cal. yr $\mathrm{BP})$. This subzone displays an increase in E. rubrum (14-82\%). $N$. dombeyi-type (16-59\%) maintains similar frequencies compared with those of the previous zone CDT-2. Caltha peaks at $53 \%$ at the beginning of the subzone followed by its virtual disappearance. Poaceae (7\%) displays low values. Sphagnum records $23 \%$.

Subzone CDT-3b (469.5-81.5 cm; 5650-1200 cal. yr $\mathrm{BP})$. During this subzone $N$. dombeyi-type shows an increase in its percentages $(41-81 \%)$ along with decreases in $E$. rubrum (8-58\%). Sphagnum reaches three peaks, up to 30 , 36 and $62 \%$.

Subzone CDT-3c (81.5-0 cm; 1200-0 cal. yr BP). This subzone is characterized by an increase in N. dombeyi-type (up to $93 \%$ ), while E. rubrum (18\%) decreases in relation to the previous Subzone CDT-3b. Between 510 and 380 cal. yr BP, N. dombeyi-type registers low frequency values
(52-67\%), while E. rubrum increases up to $47 \%$.

In this zone total pollen concentration records its highest values (405800 grains $\mathrm{gr}^{-1}$ ). The main contributor is $N$. dombeyi-type that reaches up to 277200 grains gr $^{-1}$. E. rubrum records 140200 grains gr ${ }^{-1}$ with a peak of 291100 grains gr $^{-1}$.

\section{DISCUSSION \\ Local glacial history}

In the Canal Beagle area, the LGM (ca. 25,000 cal. yr BP; Rabassa, 2008) is represented by a complex system of basal, lateral and terminal moraines. The latter moraine is located at Punta Moat, $120 \mathrm{~km}$ to the east of the Río Pipo valley, where Cañadón del Toro peat bog was formed. This event has been locally named Moat Glaciation (Rabassa et al., 1990). Recessional moraines have been identified 100 $\mathrm{km}$ west of the frontal position, at Punta Segunda, situated in the north coast of the channel. Although no absolute ages could be obtained from these moraines, a Lateglacial age was inferred (Rabassa et al., 2000).

Hall et al. (2013), based on the basal peat bog date from several sites of Cordillera Darwin $\left(54-55^{\circ} \mathrm{S} ; 69-70^{\circ} \mathrm{W}\right)$, postulated that a collapse of a massive ice in the cordillera began at 18,400 cal. yr BP, which had progressed such that ice was confined into the interior fjords by 16,800 cal. yr BP. The authors showed evidences that central Canal Beagle must have been free of ice at least at 14,800 cal. yr BP. A basal radiocarbon date from Ushuaia 2 peat bog located in the low terrains (25 m a.s.I.) along the Canal Beagle coast at Ushuaia city, confirms that this area was free of ice by 14,470 cal. yr BP; and by about 13,900 cal. yr BP (Ushuaia 1 peat bog) at elevations of $300 \mathrm{~m}$ above Ushuaia city. Eight $\mathrm{km}$ to the southwest, the landscape was free of ice by 11,640 cal. yr BP when Lapataia peat bog started to develop (Heusser, 1998).

No Lateglacial re-advances have been located and dated in the lowlands of the Canal Beagle (Rabassa et al., 2006). However, geomorphological evidences from the tributary valleys of Fuegian Andes allowed to identify moraines that demarcated advances of glaciers during the Antarctic Cold Reversal (ACR, 14,500-12,900 cal. yr BP), the Younger Dryas Chronozone (YD, 12,900-11,700 cal. yr BP), and the presence of one, and locally two, closely spaced moraines located up to $2 \mathrm{~km}$ downvalley of Little Ice Age (LIA, <1000 
cal. yr BP) (Menounos et al., 2013). In these tributary valleys, several moraine deposits related to a Holocene glacier expansion have been identified (Rabassa et al., 1990; Strelin et al., 2001; Planas et al., 2002; Menounos et al., 2013, Ponce et al., 2015). Menounos et al. (2013) have reported geological evidences for one or more advances of glaciers sometime between 7960-7340 and 5290-5050 cal. yr BP to limits only tens of meters beyond LIA maximum positions. No absolute ages are yet available for the inner moraines. However, these moraines have been assigned to advances of the LIA (<1000 cal. yr BP) based on their fresh, uneroded forms, proximity to existing ice, and similarity of their positions to moraines in the vicinity that had already been assigned to the LIA (Menounos et al., 2013). These terminal moraines descend to $680 \pm 131 \mathrm{~m}$ a.s.l. (Ponce et al., 2015). Menounos et al. (2013) suggested that the LIA event was the more extended neoglacial advance in the region.

\section{Palaeoenvironmental reconstruction at Cañadón del Toro peat bog}

After 13,500 cal. yr BP, the initial Lateglacial vegetal communities that colonized the deglaciated terrain were characterized by the dominance of pioneer grasses (Poaceae) and dwarf shrub heaths (Empetrum rubrum). By about 13,000 cal. yr BP, the spread of shrubs (Asteraceae subf. Asteroideae) along with Acaena, an indicator of open/ disturbed grounds, suggests the prevalence of grasslandshrub environments. With soil development and increased humidity, the landscape was invaded by wetland herbs such as Caltha, Gunnera, and Gentiana. Among the more frequent steppe-associated plants, Apiaceae, Rubiaceae, Caryophyllaceae and Azorella were recorded. During this interval, the Nothofagus populations were poorly represented with low frequency and concentration values. Meanwhile, mire plants were characterized mainly by the dominance of sedges (Cyperaceae) showing at this initial stage the development of a minerotrophic mire (fen). These vegetal palaeocommunities resemble the present Fuegian steppe of the northern part of Tierra del Fuego, where mean annual precipitation is less than $400 \mathrm{~mm}$ and mean annual temperatures average $5.5^{\circ} \mathrm{C}$ (Tuhkanen, 1992).

A significant vegetation change occurred by 10,350 cal. yr BP. The steppe environments were replaced by a foreststeppe ecotone that prevailed until 6500 cal. yr BP. During this interval, stands of Nothofagus forest were interspersed with shrubs (Asteraceae subf. Asteroideae), grasses (Poaceae), and herbs (Gunnera, Acaena, Apiaceae, Rubiaceae, and Gentiana). The increase in the arboreal frequencies and concentrations together with the persistence in the record of the mistletoe Misodendrum seems to be a good evidence for the local presence of Nothofagus. Analogous communities exist today in central Isla Grande de Tierra del Fuego, with annual precipitation estimated at 350-500 mm and summer temperatures averaging $11^{\circ} \mathrm{C}$ (Tuhkanen, 1992). During this period, the mire environment suggests a transitional stage between Cyperaceae fen and Sphagnum bog, due to an increase in atmospheric humidity. Between ca. 8600 and 7000 cal. yr BP, the total pollen concentration values drop abruptly, displaying synchronous fluctuations of taxa in the same direction (Fig. 5). Many complex factors such as mechanical, chemical, and biological agents, determine the differential preservation of the pollen in a specific type of deposit (Bryant, 1978). The increase in the ash during this interval (570-534 cm depth, Fig. 3) could reflect the tephra deposition process itself combined with increased mineralization of organic matter derived from the enhancement of microbial activity, resulting in a temporary alteration of trophic and water environment. The low concentration rates may also give some indication of oxidizing conditions at the mire surface probably caused by a seasonally fluctuating water table, which would account for a lack of pollen preservation (Heusser, 1998; Cook, 2009). This is in line with a reduced precipitation pattern and warmer conditions that prevailed during this period. Almost immediately after the tephra deposition, the development of new suitable habitats for pioneer plants is manifested by the increase in Caltha and Gunnera pollen.

After 6500 cal. yr BP, the pollen assemblage reflects the development of a closed-canopy Nothofagus forest spreading into the valley as a response of cooler and wetter conditions. This climate change is also evidenced in the mire setting. The increasing percentages of Sphagnum and $E$. rubrum suggest that the mire switched to ombrotrophic conditions. Sphagnum species colonize bog surface, whereas 
E. rubrum grows on dry, elevated areas such as unhumified hummocks (Birks and Birks, 1980; Markgraf and Huber, 2010). Presently, these vegetal communities develop in the south of Tierra del Fuego with annual precipitation of more than 500 mm (Tuhkanen, 1992). By about 500 cal. yr BP, Nothofagus frequencies decline along with an increase in E. rubrum pollen, followed by the return of a closed-canopy forest at the site. Rumex acetosella L. 1753, an introduced taxon, indicates vegetation disturbance, including logging, fire and grazing (Mancini, 2009).

\section{Comparison with other sites}

Lateglacial pollen evidences show a vegetation pattern dominated by a mosaic of highly diverse steppe-like communities with scarce Nothofagus trees, at Puerto Harberton, and Ushuaia 2 and 3 sites, situated in the lowlands along the Canal Beagle coast (Heusser, 1990, 1998; Markgraf and Huber, 2010). In the low interior valleys, the pollen records from Cañadón del Toro (this paper), Valle de Carbajal (Oyarzun peat bog), and National Route 3 exposure (Borromei et al., 2007), as well as Paso Garibaldi, a high-elevation site (Markgraf and Huber, 2010), display a broadly similar vegetational pattern. The vegetation probably changed following its own internal dynamics, including the spread of plants and colonization of new ground, competition for suitable habitats and succession (Fontana and Bennett, 2012). During this time, at Puerto Harberton (Fig. 7), the Nothofagus pollen data suggest the survival of small tree populations in glacial refugia, distributed within the modern forested areas outside the glacier limits (Premoli et al., 2010; Fontana and Bennett, 2012). It is likely that the early presence of the prostrate shrub Empetrum rubrum in the deglaciated valleys may have favoured the regional establishment of Nothofagus species (Fontana and Bennett, 2012). Today, the canopy of E. rubrum has an important nurse effect on growth of $N$. antarctica seedlings in the early stages of post-glacial succession by influencing microclimate and/or soil resource availability (Henríquez and Lusk, 2005). In Terra Australis mire, at central Tierra del Fuego (Fig. 1), the record of fungal remains of cf. Microthyrium fagi Ellis 1977 concurrent with increases in Nothofagus frequencies may indicate that some trees were locally present during the Lateglacial period (Musotto et al., 2016). Mi- crothyrium fagi is found on dead autumn leaves of N. pumilio (Arambarri and Gamundi, 1984); while other microthyriaceous fungi, including cf. M. fagi, have been reported in the surface samples from deciduous beech forest (Musotto et al., 2012).

Particularly, in the Cañadón del Toro sequence, there is no indication in the arboreal composition (both frequencies and concentrations) of a major cold reversal related to the ACR and the YD Chronozone. However, Heusser (1998) identified two episodes of cooling characterized by low Nothofagus influx and separated by intervals of high arboreal influx associated to warmth conditions, from dated peat bog sections (Puerto Harberton, Ushuaia 1, 2 and 3) located along the Canal Beagle coast.

The expansion of Nothofagus woodland (Fig. 7) started during the Early Holocene, by about 11,500 cal. yr BP in the low terrains at Puerto Harberton, eastward Canal Beagle, and earlier, by about 12,400 cal. yr BP, at elevations of 300 m above Ushuaia city (Ushuaia 1 site). In Cañadón del Toro, the development of woodland-dominated vegetation occurred after ca. 10,500 cal. yr BP, like in the lowlands at Ushuaia 2 and 3. In the inner valleys of Andorra and Carbajal (Oyarzun site), Nothofagus woodland spread later. It seems probable that the expansion of Nothofagus has been distinctly affected by the prevailing westerly circulation and the local conditions at different sites (e.g., soiltypes, drainage, slope, facing).

During this period, the Nothofagus populations along with the steppe communities constituted an ecotone indicating warmer and drier conditions than today. Noticeable is the increase in Misodendrum frequencies in all the pollen sequences. This mistletoe is a hemiparasite that thrives exclusively on Nothofagus species; the intensity of infestation is dependent upon light and host availability, being maximal under high luminosity conditions and intermediate Nothofagus densities (Moreno et al., 2014). High fire frequencies in Tierra del Fuego during the early Holocene must have favoured the development of open ground tracts and, at the same time, retarded the spread of the Nothofagus woodland (Whitlock et al., 2007; Markgraf and Huber, 2010). In the Terra Australis record, the mycorrhizal Glomus Tul. and C. Tul. 1845 was probably associated with the presence of grasses and shrubs indicating relatively dry environmental 
conditions, while the fungal spores of Gelasinospora Daw. 1933 have been related to fire events in the area during this time (Musotto et al., 2016).

Towards the eastern sector of the Canal Beagle, at Punta Moat site, distant $<1 \mathrm{~km}$ from the coast-line, the influence of the relative rise of the sea-level and the marine spray-humidity favoured the early development of a closedcanopy Nothofagus forest by 9500 cal. yr BP (Borromei et al., 2014) (Fig. 7). Also, in the high-elevation sites, such as Paso Garibaldi and Las Cotorras, the closed-canopy Nothofagus forest reached those altitudes by about 8800 and 8000 cal. yr BP, respectively (Fig. 7). Although no charcoal analysis was performed on Las Cotorras peat core, Markgraf and Huber (2010) indicated that fires were absent at the upper treeline at Paso Garibaldi and did not influence the Nothofagus communities there. At these elevation sites, the development of a closed-canopy forest suggests modern moisture levels with a treeline at or even above present (Markgraf and Huber, 2010). Meanwhile, dense forest populations developed after about 7000 cal. yr BP in the lowlands along Canal Beagle coast and after 6500 cal. yr $\mathrm{BP}$ in the interior valleys (Fig. 7).

There are no clear evidences for the Holocene glacier fluctuations in the vegetation composition of these fossil localities. However, the intervals of low Nothofagus influx, at 6380-5000 cal. yr BP, 2334-360 cal. yr BP and recently at Puerto Harberton, are indicative of cooler episodes (Heusser, 1989b). The first interval of decline in arboreal influx at Puerto Harberton may be related to the one of the glacier advances reported by Menounos et al. (2013) between 7960-7340 and 5290-5050 cal. yr BP. During the last 1000 years (Fig. 7), decreases in the frequency of Nothofagus pollen have been recorded in the Cañadón del Toro valley at ca. 500 cal. yr BP. In Las Cotorras, a major vegetational change towards colder conditions has been re-

Figure 7. Nothofagus pollen frequency records from Cañadón del Toro (this paper); Valle de Andorra (Borromei, 1995); Las Cotorras (Borromei et al., 2010); Paso Garibaldi (Markgraf and Huber, 2010); Puerto Harberton (Markgraf and Huber, 2010); Punta Moat (Borromei et al., 2014); and Ushuaia 2 (Heusser, 1998) sites. The peat bogs are listed according to their altitude above sea level (m a.s.l.).

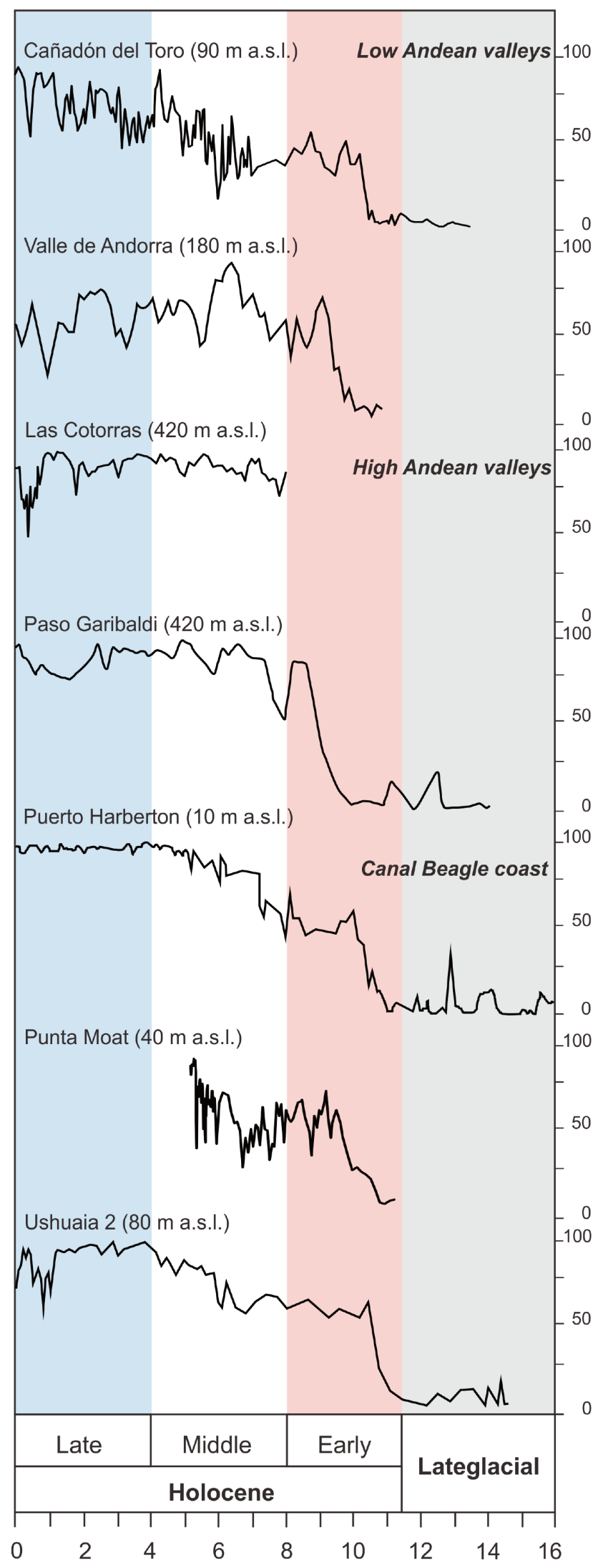

Age (cal. kyr BP) 
ported after 1000 cal. yr BP, when the decline of Nothofagus pollen reached a minimum between ca. 680 and 300 cal. yr BP. During this interval, the stratigraphy of the mire showed peat interspersed with clastic sediments. They were indicative of a clastic input coming from mass wasting events or floods occurring during snowmelt and deposited over a very short time scale (Borromei et al., 2010). Presumably, the reduced vegetal cover, due to a less dense forest, favoured the landslides downslope in the valley. The multiproxy analyses of a ca. 1400-yr peat record from Valle de Andorra also registered climatic fluctuations including a period of cooler and/or wetter conditions (Mauquoy et al., 2004). In Paso Garibaldi high-elevation site, the spread of Andean grasslands along with a less dense forest indicated the treeline lowering below the site between 2500 and 400 cal. yr BP, probably related to minor temperature depressions (Markgraf and Huber, 2010). Taken together, these pollen data could be related to the LIA (<1000 cal. yr BP) chronozone. Climatic factors, such as strength and latitudinal position of the SWW, changes in solar irradiance and in atmospheric-ocean circulation have been mentioned among the more important external drivers for Holocene glacier fluctuations in Tierra del Fuego (Menounos et al., 2013).

\section{CONCLUSIONS}

The palaeovegetation reconstruction from Cañadón del Toro peat bog show changes in the plant communities that follow similar patterns to those recorded in the lowlands and in the high-elevation sites of the forested region in southern Tierra del Fuego, although these changes were not simultaneous. For most of the Lateglacial period, after ca. 13,500 cal. yr BP, the Río Pipo valley remained with scattered Nothofagus trees and grasses, shrubs and heaths dominated the vegetation. Initially, the mire was a Cyperaceae fen. Nothofagus spread into the valley during the Early Holocene, around 10,350 cal. yr BP, like an ecotone when the climate conditions were warmer and drier than today. The regional fires may have restrained the Nothofagus forest expansion favouring the development of open ground vegetation dominated by shrubs and grasses. Meanwhile, the mire showed a transitional physiognomy between Cyperaceae fen and Sphagnum bog.

The dated tephra at $6170+/-70^{14} \mathrm{C}$ yr BP (7178-6796 cal. yr BP) seems to correspond, in chronology and composition, to the $\mathrm{H}_{1}$ tephra from the Volcán Hudson. The pollen and geochemical spectra of this event record a temporary impact during the development of the peat bog between $c a$. 8600 and 7000 cal. yr BP.

During the mid- to Late Holocene, by about 6700 cal. yr BP, a climatic change towards colder and wetter conditions may have facilitated the expansion of dense forest on the Pacific Andean slope in southernmost Tierra del Fuego. By this time, the mire also changed to ombrotrophic conditions, contributed essentially by Sphagnum, reflecting greater water depth and less mineral input. During the last 1000 cal. yr $\mathrm{BP}$, the record showed a decline in the Nothofagus frequencies at ca. 500 cal. yr BP most probably related to colder conditions. The palaeoenvironmental conditions recorded throughout the studied sequence are closely related to oscillations in precipitation and temperature as a response to the variations in the position and/or strength of the southern margin of the SWW at these high latitudes.

\section{ACKNOWLEDGEMENTS}

This contribution is dedicated to a great leader of the Palynology of South America, Prof. Dr. Mirta Elena Quattrocchio, specialist in marine and terrestrial palynology applied to Mesozoic and Cenozoic biostratigraphy and basin analysis throughout Argentina. Thanks a lot Mirta for all you have given us (and a large number of other people), for your warmly and constant support and advice not only as a Professor but also as a human being. We are grateful to the editors of this volume, Marcelo Adrián Martínez and Daniela Olivera, for the invitation to participate. We also thank to Juan Carlos Nóvoa Muñoz (Universidade de Vigo, España) for his hard work during all field campaigns and laboratory work conducted in Tierra del Fuego, to Antonio Martínez Cortizas (Universidade de Santiago de Compostela, España) and colleagues for field assistance during coring, and to Lorena Bonjour (Departamento de Agronomía, Universidad Nacional del Sur, Argentina) for helping in laboratory tasks. Two anonymous reviewers are thanked for their valuable comments on the manuscript. The APN (National Parks administration of Argentina) and personnel of Parque Nacional Tierra del Fuego allowed coring in an environmental protected site. This paper was funded by the grant Fundación BBVA (Ref. BIOCON-05 119).

\section{REFERENCES}

Arambarri, A.M., and Gamundi, I.J. 1984. Micoflora de la hojarasca de Nothofagus pumilio y N. oblicua II. Darwiniana 25: 255-265.

Birks, H.J., and Birks, H.H. 1980. Quaternary Palaeoecology. Arnold (Publishers) Limited, London, $289 \mathrm{p}$.

Borromei, A.M. 1995. Análisis polínico de una turbera holocénica en el Valle de Andorra, Tierra del Fuego, Argentina. Revista Chilena de Historia Natural 68: 311-319.

Borromei, A.M., Coronato, A., Franzén, L.G., Ponce, J.F., López Sáez, J.A., Maidana, N., Rabassa, J., and Candel, M.A. 2010. Multiproxy 
record of Holocene paleoenvironmental change, Tierra del Fuego, Argentina. Palaeogeography, Palaeoclimatology, Palaeoecology 286: 1-16.

Borromei, A.M., Coronato, A., Quattrocchio, M., Rabassa, J., Grill, S., and Roig, C. 2007. Late Pleistocene - Holocene environments in Valle Carbajal, Fuegian Andes valley, southern South America. Journal of South American Earth Sciences 23: 321-335.

Borromei, A.M., Ponce, J.F., Coronato, A., Candel, M.S., Olivera, D., and Okuda, M. 2014. Reconstrucción de la vegetación posglacial y su relación con el ascenso relativo del nivel del mar en el extremo este del canal Beagle, Tierra del Fuego. Andean Geology 41: 362-379.

Borromei, A.M., and Quattrocchio, M. 2001. Palynological study of Holocene marine sediments from Bahía Lapataia, Beagle Channel, Tierra del Fuego, Argentina. Revista Española de Micropaleontología 33: 61-70.

Borromei, A.M., and Quattrocchio, M. 2007. Palynology of Holocene marine deposits at Beagle Channel, southern Tierra del Fuego, Argentina. Ameghiniana 41: 161-171.

Borromei, A.M., and Quattrocchio, M. 2008. Late and Postglacial Paleoenvironments of Tierra del Fuego: terrestrial and marine palynological evidence. In: J. Rabassa (Ed.), The Late Cenozoic of Patagonia and Tierra del Fuego. Developments in Quaternary Science, 11, Elsevier, Amsterdam, p. 369-381.

Bryant Jr., V.M. 1978. Palynology: a useful method for determining paleoenvironments. Texas Journal of Science 45: 1-45.

Buurman, P., van Lagen, B., and Velthorst, E.J. 1996. Manual for Soil and Water Analysis. Backhuys Publishers, Leiden, $314 \mathrm{p}$.

Collantes, M.B., Anchorena, J.A., and Koremblit, G. 1989. A soil nutrient gradient in Magellanic Empetrum heathlands. Vegetation 80: 183-193.

Cook, E.J. 2009. A record of late Quaternary environments at lunette-lakes Bolac and Turangmoroke, Western Victoria, Australia, based on pollen and a range of non-pollen palynomorphs. Review of Palaeobotany and Palynology 153: 185-224.

Coronato, A. 1990. Definición y alcance de la última glaciación pleistocena (Glaciación Moat) en el Valle de Andorra, Tierra del Fuego. $11^{\circ}$ Congreso Geológico Argentino (Buenos Aires), Actas 1 : 286-289.

Coronato, A. 1993. La glaciación Moat (Pleistoceno Superior) en los valles Pipo y Cañadón del Toro, Andes Fueguinos. $12^{\circ}$ Congreso Geológico Argentino (Mendoza), Actas 6: 40-47.

Coronato, A. 1995. The last Pleistocene glaciation in tributary valleys of the Beagle Channel, Southernmost South America. Quaternary of South America and Antarctic Peninsula 9: 173-182.

Faegri, K., and Iversen, J. 1989. Textbook of pollen analysis. Wiley and Sons, Chichester, $328 \mathrm{p}$.

Fontana, S.L., and Bennett, K.D. 2012. Postglacial vegetation dynamics of western Tierra del Fuego. Holocene 22: 1337-1350.

García-Rodeja, E., Nóvoa, J.C., Pontevedra-Pombal, X., MartínezCortizas, A., and Buurman, P. 2004. Aluminium fractionation of European volcanic soils by selective dissolution techniques. Catena 56: 155-183.

Grill, S., Borromei, A.M., Quattrocchio, M., Coronato, A., Bujalesky, G., and Rabassa, J. 2002. Palynological and sedimentological analysis of Recent sediments from Río Varela, Beagle Channel, Tierra del Fuego, Argentina. Revista Española de Micropaleontología 34: 145-161.

Grimm, E. 2004. Tilia and TGView 2.0.2. Software. Illinois State Museum, Research and Collection Center, Springfield, USA.

Hall, B.L., Porter, C.T., Denton, G.H., Lowell, T.V., and Bromley, G.R.M. 2013. Extensive recession of Cordillera Darwin glaciers in southernmost South America during Heinrich Stadial 1. Quaternary Science Reviews 62: 49-55.

Henríquez, J.M., and Lusk, C.H. 2005. Facilitation of Nothofagus antarctica (Fagaceae) seedlings by the prostrate shrub Empetrum rubrum (Empetraceae) on glacial moraines in Patagonia. Austral Ecology 30: 877-882.

Heusser, C.J. 1989a. Late Quaternary Vegetation and Climate of Southern Tierra del Fuego. Quaternary Research 31: 396-406.

Heusser, C.J. 1989b. Climate and chronology of Antarctica and adjacent South America over the past 30,000 yr. Palaeogeography, Palaeoclimatology, Palaeoecology 76: 31-37.

Heusser, C.J. 1990. Late-glacial and Holocene vegetation and climate of subantarctic South America. Review of Palaeobotany and Palynology 65: 9-15.

Heusser, C.J. 1995. Palaeoecology of a Donatia-Astelia cushion bog, Magellanic Moorland-Subantarctic Evergreen Forest transition, southern Tierra del Fuego, Argentina. Review of Palaeobotany and Palynology 89: 429-440.

Heusser, C.J. 1998. Deglacial paleoclimate of the American sector of the Southern Ocean: Late Glacial-Holocene records from the latitude of Beagle Channel ( $\left.55^{\circ} \mathrm{S}\right)$, Argentine Tierra del Fuego. Palaeogeography, Palaeoclimatology, Palaeoecology 141: 277301.

Heusser, C.J. 2003. Ice age southern Andes - A chronicle of paleoecological events. Developments in Quaternary Science, 3. Elsevier, Amsterdam, $240 \mathrm{p}$.

Hogg, A.G., Hua, Q., Blackwell, P.G., Buck, C.E., Guilderson, T.P., Heaton, T.J., Niu, M., Palmer, J.G., Reimer, P.J., Reimer, R.W., Turney, C.S.M., and Zimmerman, S.R.H. 2013. SHCal13 Southern Hemisphere calibration, 0-50,000 years cal BP. Radiocarbon 55: 1889-1903.

Kilian, R., Hohner, M., Biester, H., Wallrabe-Adams, H.J., and Stern, C.R. 2003. Holocene peat and lake sediment tephra record from the southernmost Chilean Andes (53 $\left.-55^{\circ} \mathrm{S}\right)$. Revista Geológica de Chile 30: 23-37.

Kilian, R., and Lamy, F. 2012. A review of Glacial and Holocene pa-

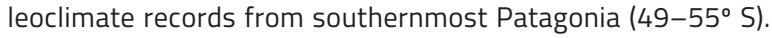
Quaternary Science Reviews 53: 1-23.

Mancini, M.V. 2009. Holocene vegetation and climate changes from a peat pollen record of the forest-steppe ecotone, Southwest of Patagonia (Argentina). Quaternary Science Reviews 28: 14901497.

Markgraf, V. 1983. Late and postglacial vegetational and paleoclimatic changes in subantarctic, temperate and arid environments in Argentina. Palynology 7: 43-70.

Markgraf, V. 1991. Late Pleistocene environmental and climatic evolution in southern South America. Bamberger Geographische Schriften 11: 271-281.

Markgraf, V. 1993. Paleoenvironments and paleoclimates in Tierra del Fuego and southernmost Patagonia, South America. Palaeogeography, Palaeoclimatology, Palaeoecology 102: 53-68.

Markgraf, V., and Huber, U.M. 2010. Late and postglacial vegetation and fire history in Southern Patagonia and Tierra del Fuego. Palaeogeography, Palaeoclimatology, Palaeoecology 297: 351366.

Mauquoy, D., Blaauw, M., van Geel, B., Borromei, A.M., Quattrocchio, M.E., Chambers, F., and Possnert, G. 2004. Late-Holocene climatic changes in Tierra del Fuego based on multi-proxy analyses of peat deposits. Quaternary Research 61: 148-158.

Menounos, B., Clague, J.J., Osborn, G., Thompson Davis, P., Ponce, J.F., Goehring, B., Maurer, M., Rabassa, J.O., Coronato, A., and Marr, R. 2013. Latest Pleistocene and Holocene glacier fluctua- 
tions in southernmost Tierra del Fuego, Argentina. Quaternary Science Reviews 77: 70-79.

Moore, D.M. 1983. Flora of Tierra del Fuego. Nelson, Oswestry, 396 p. Moreno, P.I., Vilanova, I., Villa-Martínez, R.P., Garreaud, R.D., Rojas, M., and De Pol-Holz, R. 2014. Southern Annular Mode-like changes in southwestern Patagonia at centennial timescales over the last three millenia. Nature communications 5: 4375.

Musotto, L.L., Bianchinotti, M.V., and Borromei, A.M. 2012. Pollen and fungal remains as environmental indicators in surface sediments of Isla Grande de Tierra del Fuego, southernmost Patagonia. Palynology 36: 162-179.

Musotto, L.L., Borromei, A.M., Bianchinotti, M.V., and Coronato, A. 2016. Late Quaternary palaeoenvironmental reconstruction of central Tierra del Fuego (Argentina) based on main fossil pollen and fungi. Quaternary International. DOI:10.1016/j.quaint. 2016.01.071

Pendall, E., Markgraf, V., White, J.W.C, Dreier, M., and Kenny, R. 2001. Multiproxy record of late Pleistocene - Holocene climate and vegetation change in Patagonia. Quaternary Research 55: 168-178.

Pisano, E. 1977. Fitogeografía de Fuego-Patagonia Chilena. I.- Comunidades vegetales entre las latitudes $52^{\circ}$ y $56^{\circ} \mathrm{S}$. Anales Instituto de la Patagonia 8: 121-250.

Planas, X., Ponsa, A., Coronato, A., and Rabassa, J. 2002. Geomorphological evidence of different glacial stages in the Martial cirque, Fuegian Andes, southernmost South America. Quaternary International 87: 19-27.

Ponce, J.F., Menounos, B., Fernadez, M., and Schaefer, J. 2015. Chronology and extent of autermost cirque moraines in the southernmost Fuegian Andes and Canadian Cordillera. $6^{\circ} \mathrm{Con}$ greso Argentino de Cuaternario y Geomorfología (Ushuaia), Resúmenes, p. 225.

Pontevedra-Pombal, X., Mighall, T.M., Nóvoa-Muñoz, J.C., PeiteadoVarela, E., Rodríguez-Racedo, J., García-Rodeja, E., and Martínez-Cortizas, A. 2013. Five thousand years of atmospheric $\mathrm{Ni}, \mathrm{Zn}, \mathrm{As}$, and Cd deposition recorded in bogs from NW Iberia: prehistoric and historic anthropogenic contributions. Journal of Archaeological Science 40: 764-777.

Premoli, A.C., Mathiasen, P., and Kitzberger, T. 2010. Southernmost Nothofagus trees enduring ice ages: genetic evidence and ecological niche retrodiction reveal high latitude $\left(54^{\circ} \mathrm{S}\right)$ glacial refugia. Palaeogeography, Palaeoclimatology, Palaeoecology 298: 247-256.

Prohaska, F. 1976. The climate of Argentina, Paraguay and Uruguay. In: W. Schwerdfeger (Ed.), Climates of Central and South America. World Survey of Climatology, 12, Elsevier, Amsterdam, p. $13-112$.

Rabassa, J. 2008. Late Cenozoic glaciations in Patagonia and Tierra del Fuego. In: J. Rabassa (Ed.), The Late Cenozoic of Patagonia and Tierra del Fuego. Developments in Quaternary Science 11, Elsevier, Amsterdam, p. 151-204.

Rabassa, J., Coronato, A., Bujalesky, G., Salemme, M., Roig, C., Meglioli, A., Heusser, C., Gordillo, S., Roig, F., Borromei, A., and Quattrocchio, M. 2000. Quaternary of Tierra del Fuego, Southernmost South America: an updated review. Quaternary International 68-71: 217-240.
Rabassa, J., Coronato, A., Heusser, C.J., Roig Juñent, F., Borromei, A., Roig, C., and Quattrocchio, M. 2006. The peatbogs of Argentine Tierra del Fuego as a source for paleoclimatic and paleoenvironmental information. In: I. P. Martini, A. Martínez Cortizas, and W. Chesworth (Eds.), Peatlands: Evolution and Records of Environmental and Climate Changes. Developments in Earth Surface Processes Series 9, Elsevier, Amsterdam, p. 129-144.

Rabassa, J., Heusser, C., and Rutter, N. 1990. Late-Glacial and Holocene of Argentine Tierra del Fuego. Quaternary of South America \& Antarctic Peninsula 7: 327-351.

Stern, C.R. 2008. Holocene tephrochronology record of large explosive eruptions in the southernmost Patagonian Andes. Bulletin of Volcanology 70: 435-454.

Stockmarr, J. 1971. Tablets with spores used in absolute pollen analysis. Pollen et Spores 13: 615-621.

Strelin, J., Casassa, G., Rosqvist, G., and Holmlund, P. 2001. Glaciaciones Holocénicas en el valle del glaciar Ema, monte Sarmiento, Tierra del Fuego. Simposio Internacional Cambios vegetacionales y climáticos durante el último ciclo glacial-interglacial a lo largo de Chile continental (Chile), Resúmenes, 16 p.

Stuiver, M., Reimer, P.J., and Reimer, R.W. 2015. Calib 7.1: computer program for radiocarbon calibration. World Wide Web: http: //calib.qub.ac.uk/calib/

Telford, R.J., Heegaard, E., and Birks, H.J.B. 2004. The intercept is a poor estimate of a calibrated radiocarbon age. Holocene 14: 296-298.

Trivi de Mandri, M.E., Burry, L.S., and D'Antoni, H.L. 2006. Dispersión-depositación del polen actual en Tierra del Fuego, Argentina. Revista Mexicana de Biodiversidad 77: 89-95.

Tuhkanen, S. 1992. The climate of Tierra del Fuego from a vegetation geographical point of view and its ecoclimatic counterparts elsewhere. Acta Botanica Fennica 125: 4-17.

Whitlock, C., Moreno, P., and Bartlein, P. 2007. Climatic controls of Holocene fire patterns in southern South America. Quaternary Research 68: 28-36.

Doi: 10.5710/PEAPA.24.03.2016.91

Recibido: 27 de noviembre de 2015

Aceptado: 24 de marzo de 2016 